\title{
Karakteristik Kualitas Kimia Daging Sapi Bali Di Pasar Tradisional
}

\author{
Andi Fausiah ${ }^{1}$, Ihwan Pausan Al Buqhori ${ }^{2}$ \\ Program Studi Peternakan Universitas Al Asyariah Mandar \\ andifausiah31@gmail.com
}

\begin{abstract}
Abstrak
Tujuan penelitian ini untuk mengetahui kualitas daging secara uji kimia (kadar protein,kadar air,kadar lemak,kadar karbohidrat dan kadar abu) daging sapi yang berasal dari pasar tradisional di kabupaten Polewali Mandar. Penelitian ini akan dilaksanakan selama 1 bulan mulai akhir april sampai akhir mei 2018 di Rumah Potong Hewan (RPH) di kecamatan Wonomulyo dan Laboratorium Nutrisi Makanan Ternak, Fakultas Peternakan, Universitas Hasanuddin, Makassar. Penelitian dilakukan Pengambilan sampel setelah ternak disembelih (setelah proses boneless) pada bagian otot Longisimus Dorsi, Biceps Femoris, Pectoralis Profundus, Gastrocnemius Kemudian sampel dimasukkan kedalam cool box yang berisi es batu, lalu dibawa ke Laboratorium Nutrisi dan Makanan Ternak Setelah itu daging dibersihkandari lemak dan jaringan ikat untuk dilakukan pengujian Kadar Protein, Kadar air, Kadar lemak, dan kadarAbu. Hasil penelitian menunjukkan kisaran kadar air daging sapi bali pada market yang berbeda berkisar 74,84-77,98\%. Kadar air yang dihasilkan masih dalam kisaran normal. Kadar protein yang dihasilkan 88,58-89,53\% Artinya, penanganan yang berbeda pada setiap pemilik market menghasilkan kadar protein daging sapi bali yang cenderung berbeda. Kadar lemak yang dihasilkan berkisar $0,15-0,26 \%$ rendahnya kadar lemak daging pada penelitian ini diduga akibat perbedaan kualitas pakan dan umur ternak sapi bali yang diteliti. rataan kadar abu daging sapi bali pada market yang berbeda berkisar antara 4,44-4,87\%. lama penyimpanan yang berbeda menghasilkan kadar abu pada sapi bali yang berbeda-beda. Dapat disimpulkan bahwa daging sapi bali yang berada pada pasar tradisional wonomulyo pada market yang berbeda membarikan pengaruh yang berbeda sangat nyata terhadap karakteristik kualitas kimia.
\end{abstract}

Keywords: Daging sapi Bali, Kualitas Kimia

\section{Pendahuluan}

Kualitas kimia daging dipengaruhi oleh faktor sebelum dan setelah pemotongan. Faktor sebelum pemotongan yang dapat mempengaruhi kualitas daging adalah genetik, spesies bangsa, dan bahan aditif (hormon, antibiotik dan mineral) serta keadaan stress, (Soeparno 2009).

Faktor setelah pemotongan meliputi kualitas kadar air, kadar lemak, dan kadar protein. Rata-rata komposisi kimia daging sapi yaitu protein bervariasi antara $16-22 \%$, lemak $1,5-13 \%$, senyawa nitrogen non protein $1,5 \%$, senyawa anorganik $1 \%$, karbohidrat $0,5 \%$, dan air antara 65-80\% (Soeparno, 2005).

Ciri suatu otot mempunyai hubungan yang erat dengan fungsinya, karena fungsinya maka jumlah jaringan ikat berbeda diantara otot. Jaringan ikat ini behubungan dengan kealotan daging. Lebih lanjut (Lawrie, 2003) mengemukakan bahwa, perbedaan kadar protein daging dapat disebabkan oleh adanya perbedaan struktur dan tingkat aktifitas otot. Dengan adanya perbedaan macam otot menunjukan adanya perbedaan distribusi nitrogen sehingga tingkat aktivitas otot yang berbeda dapat menghasilkan kadar protein daging yang berbeda pula. Sehingga perlu dilakukan penelitian untuk mengetahui karakteristik kimia daging pada jenis otot yang berbeda.

Berdasarkan latarbelakang diatas, maka dilakukan penelitian dengan judul karakteristik kimia daging sapi bali pada berbagai lokasi otot yang berbeda di Rumah Potong Hewan (RPH).

\section{Metode Penelitian}

Penelitian ini akan dilaksanakan selama 1 bulan mulai akhir april sampai akhir mei 2018 di Rumah Potong Hewan (RPH) di kecamatan Wonomulyo dan Laboratorium Nutrisi Makanan Ternak, Fakultas Peternakan, Universitas Hasanuddin, Makassar

Materi penelitian ini adalah daging sapi yang diperoleh dengan membeli langsung di RPH (Rumah Potong Hewan) dikecamatan wonomulyo. Jumlah daging sapi bali yang akan digunakan pada penelitian ini adalah 200 gram daging/otot.

Alat yang digunakan dalam penelitian ini adalah ember, cawan porselin, gegep, oven, eksikator, labu khjehdal $100 \mathrm{ml}$, labu ukur $100 \mathrm{ml}$, labu semprot, alat penyuling Nitrogen, pemanas listrik, lemari asam, buret asam, pompa pengisap, timbangan, dan erlenm eyer.

\section{Prosedur Penelitian}

Pengambilan sampel setelah ternak disembelih (setelah proses boneless) pada bagian otot Longisimus Dorsi, Biceps Femoris, Pectoralis Profundus, Gastrocnemius Kemudian sampel dimasukkan kedalam cool box yang berisi es batu, lalu dibawa ke Laboratorium Nutrisi dan Makanan Ternak, Fakultas Peternakan, Universitas Hasanuddin. Setelah itu daging dibersihkan dari lemak dan jaringan ikat.

\section{Rancangan Penelitian}

Penelitian ini dilakukan dengan metode rancangan acak lengkap (RAL) dengan 4 perlakuan dan 3 ulangan. Perlakuan pada penelitian ini adalah sebagai berikut:

A1 $=$ Otot Longissimus dorsi (Punggung) 


$$
\begin{aligned}
& \text { A2 }=\text { Otot Biceps femoris (Paha) } \\
& \text { A } 3=\text { Otot Pectoralis profundus (Dada) } \\
& \text { A } 4=\text { Otot Gastrocnemius (Betis) }
\end{aligned}
$$

\section{Hasil dan Pembahasan}

Kualitas kimia daging sapi bali mudah mengalami kerusakan, sehingga menyebabkan daging rusak dan tidak layak konsumsi. Untuk itu perlu adanya penanganan agar mutu daging sapi dapat dipertahankan. Rataan persentase kadar air, kadar protein kasar, kadar lemak, kadar abu, BETN, pada daging sapi bali yang berada pada pasar tradisional wonomulyo disajikan pada Tabel 1.

Tabel 1. Rataan Mutu Daging Sapi Bali yang berada di pasar tradisional wonomulyo

\begin{tabular}{lcccc}
\hline \multicolumn{1}{c}{ Variabel } & \multicolumn{3}{c}{ Perlakuan } & \multirow{2}{*}{ Sig } \\
\cline { 2 - 4 } penelitian & P1 & P2 & P3 & \\
\hline $\begin{array}{l}\text { Kadar Air (\%) } \\
\text { Protein Kasar (\%) }\end{array}$ & 74,85 & 77.98 & 74,95 & 76,56 \\
$\begin{array}{l}\mathrm{P}<0,01 \\
\text { Kadar Lemak (\%) }\end{array}$ & 0,22 & 89,78 & 88,58 & 89,11 \\
$\begin{array}{l}\mathrm{P}<0,01 \\
\text { Kadar Abu (\%) }\end{array}$ & 4,58 & 0,15 & 0,26 \\
$\mathrm{P}<0,01$ & 4,58 & 4,87 & 4,44 \\
\hline
\end{tabular}

Kadar air merupakan persentase kandungan air suatu bahan yang dapat dinyatakan berdasarkan berat basah atau berat kering. Hasil sidik ragam menunjukkan bahwa daging sapi dengan perlakuan market yang berbeda memberikan perbedaan yang sangat nyata $(\mathrm{P}<0,01)$ terhadap kadar air daging sapi bali. Hasil penelitian kisaran kadar air daging sapi bali pada market yang berbeda berkisar 74,84-77,98\%. Kadar air yang dihasilkan masih dalam kisaran normal sesuai dengan kadar air yang dilaporkan oleh Soeparno (2009) yakni $65-80 \%$. Data di atas menunjukkan bahwa ada pengaruh terhadap kadar air daging sapi bali pada market yang berbeda. Hal ini dikarenakan semakin lama penyimpanan daging, maka kadar air daging sedikit berkurang sehingga menyebabkan tidak terjadi tekanan osmosis dari daging ke jus gambir. Kuntoro et al., (2007) menyatakanbahwa menurunnya kadar air disebabkan adanya tekanan osmosis. Tekanan osmosis merupakan pertukaran air antara sel dengan lingkungan karena perbedaan konsentrasi.

Protein merupakan komponen kimia terbesar dalam daging yang mempunyai peranan penting bagi pertumbuhan, perawatan sel serta sebagai sumber kalori. Hasil sidik ragam menunjukkan bahwa perlakuan yang diberikan pada daging sapi bali pada pasar tradisional wonomulyo memberikan pengaruh yang berbeda sangat nyata $(\mathrm{P}<0,01)$ terhadap market yang berbeda. Artinya, penanganan yang berbeda pada setiap pemilik market menghasilkan kadar protein daging sapi bali yang cenderung berbeda.

Abustam (2009) Rendahnya kadar protein pada penelitian ini diduga karena terjadi absorbsi air yang masuk ke dalam jaringan otot daging dan mengakibatkan terjadinya denaturasi protein urat daging yang menyebabkan meningkatnya penyerapan air kedalam ruang ekstraseluler dan intraseluler sehingga kadar protein menjadi rendah (Prasetyo, 2009). Diduga meningkatnya kadar lemak daging dalam penelitian ini juga menjadi salah satu penyebab rendahnya kadar protein yang dihasilkan, seperti yang dikemukakan oleh Idriastuti (2012) bahwa kadar protein menurun selama masa simpan diduga karena ada hubungan dengan nilai kadar air dan lemak yang cenderung meningkat 39 namun sangat kecil.

Lemak merupakan salah satu sumber energi yang memberikan kalori paling tinggi. Hasil sidik ragam menunjukkan bahwa daging sapi bali yang berada di pasar tradisional wonomulyo memberikan pengaruh yang sangat nyata $(\mathrm{P}<0,01)$ terhadap kadar lemak daging sapi bali pada market yang berbeda. Artinya, jenis sapi bali yang disembelih pada market yang berbeda menghasilkan kadar lemak yang berbeda pula. Hasil penelitian menunjukkan bahwa nilai rata-rata kadar lemak daging sapi bali yang dihasilkan berkisar antara $0,15-0,26 \%$. Hal ini menjelaskan bahwa daging sapi bali pada setiap market memiliki kadar lemak yang rendah ini diduga akibat perbedaan kualitas pakan dan umur ternak sapi bali yang diteliti. dilaporkan Edrisyanto (2016) yaitu 13,29-16,64\%. Akan tetapi, kandungan lemak pada daging yang diteliti ini cenderung lebih tinggi dari apa yang dikemukakan oleh Abustam (2009) bahwa kandungan lemak daging sapi bali berkisar 1,564,31\%. Tingginya kadar lemak daging pada penelitian ini diduga akibat perbedaan kualitas pakan dan umur ternak sapi bali yang diteliti. Kadar abu merupakan komponen zat anorganik yang tidak terbakar dalam proses pembakaran. Hasil sidik ragam menunjukkan bahwa daging sapi bali yang berada pada psar tradisional wonomulyo memberikan pengaruh yang sangat nyata $(\mathrm{P}<0,01)$ terhadap kadar abu daging sapi bali pada market yang berbeda. Artinya, lama penyimpanan yang berbeda menghasilkan kadar abu pada sapi bali yang berbeda-beda. Data hasil penelitian disajikan pada Tabel 3.

Hasil penelitian menujukkan rataan kadar abu daging sapi bali pada market yang berbrda berkisar antara 4,44-4,87\%. Menurut Sugeng (2004), makanan yang berasal dari sumber hewani yang memiliki kadar abu yang tinggi, hal ini disebabkan karena beberapa mineral yang terkandung didalamnya seperti kalsium, besi, dan phosfat. Tinggi rendahnya kadar abu ditentukan adanya kandungan mineral sukar larut dalam daging. Namun karena rendahnya konsentrasi yang diberikan akan menyebabkan penguapan karena kandungan yang terdapat dalam jus gambir berupa katekin yang sifatnya sukar larut dalam air dingin sehingga dapat menurunkan kadar mineral dalam daging. Winarno (2004) menyatakan bahwa peningkatan kadar air dalam bahan pangan akan menyebabkan penurunan konsentrasi kadar abu. Selain itu, diduga pada proses pengabuan, bahan-bahan organik akan mengalami penguapan dan meninggalkan sisa pembakaran berupa mineral yang tidak menguap pada saat pemanasan. Kadar abu daging sapi juga ditentukan oleh bangsa sapi, bangsa sapi bos taurus mempunyai kadar abu lebih tinggi dari bangsa sapi bos indicus. Faktor lingkungan terutama feed intake dan kandungan 
nutrisi bahan pakan juga menentukan kadar abu daging sapi (Soeparno, 2009).

\section{Kesimpulan :}

'Berdasarkan penelitian yang telah dilaksanakan dapat disimpulkan bahwa daging sapi bali yang berada pada pasar tradisional wonomulyo pada market yang berbeda memberikan pengaruh yang berbeda sangat nyata terhadap karakteristik kualitas kimia.

\section{Daftar Pustaka}

Abustam, E. 2009. Sifat-sifat Daging Segar. Available at gttp/www.cinnatalemien eabustam.blogs.

Indriastuti, M. 2012. "Analisi Kualitas Auditor dan Corporate Governance Terhadap Manajemen Laba". Eksistansi (ISSN 2085-2401), Vol. IV, No. 2, Agustus 2012.

Kuntoro, B., I. Mirdhayati dan T. Adelina. 2007. Penggunaan ekstrak daun katuk (Sauropus androgunus L.Merr) sebagai bahan pengawet alami daging sapi segar. J. Peternakan. 4(1) : 612.

Lawrie, R.A 2013. Ilmu daging .Edisi Ke-5 . Diterjemahkan oleh prakkasi ,A,Dan.Y.Anwila universitas indonesia press, jakarta.

Prasetyo, P. Eko. 2009. Fundamental Makro Ekonomi. Yogyakarta: Beta Offset.

Seoparno. 2005. Ilmu dan Teknologi Daging. Cetakan ke empat. UGM Press: Yogyakarta.

Seoparno. 2009. Ilmu dan Teknologi Daging. Cetakan ke empat. UGM Press: Yogyakarta.

Sugeng, Y.B., 2004. Pembiakan Ternak Sapi. Gramedia. Jakarta.

Winarno, F. G. dan S. Koswara. 2002. Telur : Komposisi, Penanganan, dan. Pengolahannya. M-Brio Press 